NBER WORKING PAPER SERIES

\title{
JUDICIAL LOBBYING: THE POLITICS OF LABOR LAW CONSTITUTIONAL INTERPRETATION
}

\author{
Matias Iaryczower \\ Pablo T. Spiller \\ Mariano Tommasi \\ Working Paper 11317 \\ http://www.nber.org/papers/w11317 \\ NATIONAL BUREAU OF ECONOMIC RESEARCH \\ 1050 Massachusetts Avenue \\ Cambridge, MA 02138 \\ May 2005
}

\begin{abstract}
We would like to thank Andy Atkeson, Juliana Bambaci, Rui de Figueiredo, Christian Hellwig, David K. Levine, Leeat Yariv and seminar participants at MPSA, UCLA and Berkeley for helpful comments. The authors can be reached at miaryc@ucla.edu, spiller@haas.berkeley.edu, and tommasi@udesa.edu.ar. Please send all correspondence to Pablo Spiller, Haas School of Business, University of California at Berkeley, Berkeley, CA 94720, or via e-mail. The views expressed herein are those of the author(s) and do not necessarily reflect the views of the National Bureau of Economic Research.

(O2005 by Matias Iaryczower, Pablo T. Spiller, and Mariano Tommasi. All rights reserved. Short sections of text, not to exceed two paragraphs, may be quoted without explicit permission provided that full credit, including $\odot$ notice, is given to the source.
\end{abstract}


Judicial Lobbying: The Politics of Labor Law Constitutional Interpretation Matias Iaryczower, Pablo T. Spiller, and Mariano Tommasi

NBER Working Paper No. 11317

May 2005

JEL No. K4, O1

\begin{abstract}
$\underline{\text { ABSTRACT }}$
This paper links the theory of interest groups influence over the legislature with that of congressional control over the judiciary. The resulting framework reconciles the theoretical literature of lobbying with the negative available evidence on the impact of lobbying over legislative outcomes, and sheds light to the determinants of lobbying in separation-of-powers systems. We provide conditions for judicial decisions to be sensitive to legislative lobbying, and find that lobbying falls the more divided the legislature is on the relevant issues. We apply this framework to analyze supreme court labor decisions in Argentina, and find results consistent with the predictions of the theory.

Matias Iaryczower

UCLA

miaryc@ucla.edu

Pablo Spiller

University of California

Walter A. Haas School of Business

Faculty Bldg. 593

Berkeley, CA 94720

and NBER

spiller@haas.berkeley.edu

Mariano Tommasi

Universidad de San Andres

tommasi@udesa.edu.ar
\end{abstract}


The theoretical literature on interest group politics has put the emphasis on the link between lobbying and legislative outcomes. The empirical evidence, however, provides scant support for this connection (see Ansolabehere, de Figueiredo and Snyder 2002). ${ }^{1}$ The thrust of this paper is that the impact of lobbying has to be analyzed not in the votes of the legislature, but rather in the actions of the courts (and the agencies), where much policy making in modern societies is done. We focus on two intimately related questions. How do the interactions between a legislature and a formally independent judiciary shape the incentives for interest groups to engage in costly lobbying activities? Under what conditions will lobbying effectively influence policy outcomes in this setting?

The literature on interest group politics considers two broad avenues through which lobbying influences policy outcomes. The first class of models encompasses different forms of vote buying in legislatures, emphasizing the role of campaign contributions (Denzau and Munger 1986; Snyder 1990, 1991; Baron 1994). The second considers the so-called informational lobbying: interest groups supply government officials with information, inducing policy outcomes closer to their preferred policies (Ainsworth 1993; Austen-Smith 1993; Lohmann 1995; Rasmusen 1993). The legislature is here also taken as the relevant policy-making arena, based (implicitly or explicitly) on the fact that the information generated by lobbyists can, in general, be related to the electoral salience of a lobbyist's cause (Ainsworth 1993; de Figuereido 2002).

The fact that lobbying may influence directly only legislators' payoffs does not imply, however, that it is sensible to focus on legislatures as the only relevant policymaking body. To the contrary, as long as courts have influence on policy outcomes, the asymmetric impact of lobbying on the payoffs of the court and the legislature will shape 
its effectiveness to affect policy in equilibrium, and thus the incentives for interest groups to engage in costly lobbying activities in the first place.

The overall effect of this asymmetry rests crucially on the relation between the judiciary and the legislature. While most judiciaries are isolated from direct public approval, they are not immune from elected politicians' influence. Indeed, in most democracies, judicial decisions are not the last word. Legislatures can normally reverse judicial statutory rulings with a simple majority, although overturning constitutional rulings normally requires a higher level of political consensus. The legislature can, furthermore, affect the court's incentives by imposing sanctions such as court enlargements (Gely and Spiller 1992), impeachments (Iaryczower, Spiller and Tommasi 2002), and in some countries simply by not reappointing them. ${ }^{2}$

The court, then, can be effectively constrained in its decisions by the majorities in government. This is the essence of the so-called, "separation of powers" literature: public opinion alters judicial decisions, but does so only indirectly, by affecting the composition and preferred policies of members of the legislature (see Segal 1997, and Bergara, Richman and Spiller 2003 for a discussion).

In this paper we consider the separation-of-powers logic within a model of informative lobbying. In this environment, the political constraints faced by the court do not reflect public opinion directly, but are driven instead by the actions undertaken by an interest group. By focusing on the incentives of interest groups to lobbying only when such actions effectively influence policy outcomes, our approach provides conditions under which previous accounts of interest group influence on politicians can still survive, 
while reconciling the implications of these theoretical arguments with the weak empirical support for the connection between lobbying and legislative outcomes.

In the next sections, we develop these arguments formally, and derive empirical implications of our analysis. We then apply this framework to empirically study the politics of labor law constitutional interpretation in Argentina from 1935 to 1998.

\section{Lobbying Under Separation of Powers}

\section{The Model}

There are two individual players, the court and the interest group, and a legislature populated by a continuum of legislators with total size one. To fix ideas, in what follows we will refer to the interest group simply as the union. Policy space is $X=[0,1]$, and given ideal policy $z_{i}$, player $i$ has preferences over policies $x \in X$ represented by a utility

function $u_{i}\left(x, z_{i}\right)=-\frac{1}{2}\left(x-z_{i}\right)^{2} \cdot{ }^{3}$ Without loss of generality, we assume that the union's ideal policy is at the right extreme of the policy space, $z_{u}=1$, and refer to policy $x$ ' as being pro-labor with respect to $x^{\prime \prime}$ whenever $x^{\prime}>x^{\prime}$.'

Legislators and the court differ in their responsiveness to voters. In particular, we assume that the court is completely unresponsive to the position of voters in the policy space, and denote its preferred policy by $z_{\mathrm{c}} \in X$. We assume, though, that legislators are, at least partially, responsive to voters' stance on the issue. Assuming for simplicity that the distribution of voters in the policy space can be characterized by a single parameter $\theta \in X$, we let the ideal policy of legislator $j$ be given by $z_{L j}\left(\theta ; \beta_{j}\right)=\beta_{j}+h \theta$, where for all $j, \beta_{j}>0$ and $\beta_{j}+h<1$. The parameter $h$ allows us to capture varying degrees of voters' influence on legislators' preferred policies. The degree of conflict in the legislature is captured by the distribution of points $\beta_{j}$ across members of the legislature, 
which we describe by the cumulative distribution $G($.$) ; i.e., for any point \beta, G(\beta)$ denotes the proportion of legislators for which $\beta_{j}<\beta$.

Policy outcomes result from the interaction of the court and the legislature. While the precise form of this interaction depends on specific institutional details, in most polities the elective body can ultimately impose its will under some sufficiently demanding procedure. This final stage is the one we represent in the model: the court chooses a ruling $x_{c} \in X$, which the legislature can reverse with the votes of a majority $m \in$ $[1 / 2,1]$ of legislators. We say that a court's ruling is "stable" in the legislature - and therefore final - if there exists no alternative policy that a majority $m$ of legislators would prefer to it in a binary choice, and denote the set of stable rulings given the majority rule $m$ by $S_{m}$.

Legislators and the court are uninformed about the realization of $\theta$, and have common prior beliefs represented by the cumulative distribution function $F($.$) with$ density $f(\cdot)$. We assume that $f(\cdot)$ has full support (i.e., $f(\theta)>0$ for all $\theta \in X$ ), but otherwise allow prior beliefs to be completely arbitrary. Informally, this means that legislators can potentially be very well (but not perfectly) informed about the realization of $\theta$. In contrast, the union is perfectly informed about the realization of $\theta$, and can potentially credibly transmit this information through lobbying, which takes here the form of strikes and public demonstrations. In particular, given a realization $\theta^{\prime}$, the union can organize an observable level $a$ of demonstrations bearing a $\operatorname{cost} C\left(a, \theta^{\prime}\right)$. We will assume that $C(\cdot)$ is twice differentiable, that for every realization of the median voter $\theta, C(0, \theta)=0$, $C_{\mathrm{a}}(a, \theta)>0$, and that $C_{\mathrm{a} \theta}(a, \theta)<0$; i.e., the marginal cost of lobbying is decreasing in the 
pro-labor stance of the population. For simplicity of exposition, we will further assume that $C(a, \theta)=a(k-\theta), k>1$.

The timing of the game can thus be described as follows: (i) $\theta$ is realized and privately observed by the union; (ii) the union decides a publicly observable level of lobbying intensity $a$; and (iii) the court chooses a ruling $x_{c}$ in the set of stable policies in the legislature $S_{m}{ }^{4}$

An equilibrium is a triplet $\Gamma=\left\{\chi(\cdot), x_{\mathrm{c}}(\cdot), F(\cdot \mid a)\right\}$ consisting of $(i)$ a strategy for the union, $\gamma: X \rightarrow R_{+}$, mapping "types" $\theta$ to levels $a$ of lobbying intensity $a$, (ii) a strategy for the court, $x_{\mathrm{c}}: R_{+} \rightarrow S_{m}$, mapping observations of lobbying levels $a$ to stable rulings $x_{c} \in S_{m}$, and (iii) beliefs $F(\mid a)$ by the court and the legislators such that:

(a) $\gamma(\theta) \in \underset{a \in R_{+}}{\arg \max } u_{u}\left(x_{c}(a)\right)-C(a, \theta) \quad \forall \theta \in X$;
(b) $x_{c}(a) \in \underset{x \in X}{\arg \max }\left\{u_{c}(x): x \in S(m \mid a)\right\} \quad \forall a \in R_{+}$, and
(c) whenever $a \in \gamma(X), F(\cdot \mid a)$ is determined from $F(\cdot)$ and $\gamma(\cdot)$ using Bayes' rule.

In addition, we supplement this equilibrium concept with a refinement restricting beliefs off the equilibrium path known as criterion D1 (Banks and Sobel 1987; Cho and Kreps 1987). ${ }^{5}$

\section{The Symmetric Information Benchmark}

We first characterize, as a benchmark, the symmetric information equilibrium. Note that in this case legislators are perfectly informed about the value of $\theta$, and the union derives no benefit from lobbying, irrespective of the preferences of the electorate. Hence, there will be no lobbying in equilibrium. The relationship between preferences of the electorate 
and policy outcomes in the symmetric information environment, however, is the key element determining the amount and effectiveness of lobbying in the private information environment.

We start by characterizing the set of stable policies in the legislature given majority rule $m$. Letting $\beta_{L}^{m} \equiv G^{-1}(1-m)$ and $\beta_{H}^{m} \equiv G^{-1}(m)$, it is easy to see that $S_{m}(\theta)=\left[z_{L}\left(\theta ; \beta_{L}^{m}\right), z_{L}\left(\theta ; \beta_{H}^{m}\right)\right]$. That is, $\beta_{L}^{m}$ is the critical legislator for a pro-labor coalition, in the sense that any policy $x$ to the left of her preferred policy would be replaced by a more pro-labor policy. Similarly, $\beta_{H}^{m}$ is the critical legislator for an antilabor coalition, in that any policy to the right of her will be replaced by a more anti-labor policy. Note that $\beta_{L}(m) \leq \beta_{H}(m)$, and $\beta_{L}(m)=\beta_{H}(m)$ only with simple majority rule $(m=1 / 2)$, in which case $S_{m}(\theta)$ collapses to the preferred policy of the median voter in the legislature, and the court has no policy making power. It follows that for $m>1 / 2$, the set of possible court's ideal policies that would be stable given $\theta$ has positive measure. ${ }^{6}$

The court will then select its ideal policy unless it is constrained either for being "extremely" pro-labor or anti-labor in relation to the relevant players in congress. In particular, since the preferred policy of every legislator is strictly increasing in $\theta$, a higher value of $\theta$ results in a pro-labor shift of the entire set of stable policies. A court with a fixed policy preference $z_{c}$ may then become a "pro-labor" court for a legislature observing a low realization $\theta^{\prime}\left(z_{c}>z_{L}\left(\theta^{\prime} ; \beta_{H}\right)\right)$, or an "anti-labor" court for a legislature observing a high realization $\theta^{\prime \prime}\left(z_{c}<z_{L}\left(\theta^{\prime \prime} ; \beta_{L}\right)\right)$. Figure 1 depicts in bold the resulting court's equilibrium rulings as a function of the state of nature, $\theta$.

$<$ Figure 1 about here $>$ 
The two parallel lines in the figure represent the preferences of the critical legislators as a function of the state of nature, $z_{L}\left(\theta ; \beta_{L}\right)=\beta_{L}+h \theta$ and $z_{L}\left(\theta ; \beta_{H}\right)=\beta_{H}+h \theta$. For each $\theta$, the set of stable policies $S(\theta)$ is the segment between these lines, the interval $\left[\beta_{L}+h \theta, \beta_{H}+h \theta\right]$ in the vertical axis. If, for some $\theta$, the court's ideal point $z_{c}$ is in $S(\theta)$, the court will be able to rule according to its preferred policy, facing no effective legislative constraints. In the example depicted in the figure, this occurs for all states between the (interior) points $\theta_{0}$ and $\theta_{1}$. In this region, then, the flat portion of the bold line represents the court's equilibrium ruling. For $\theta<\theta_{0}$, however, $S(\theta)$ is entirely below $z_{c}$. Thus, if it were common knowledge among legislators that public sentiment is strongly anti-labor, the ideal point of the court would not survive the challenge of a more anti-labor legislation. The best choice for the court in such states is, therefore, to enact the most pro-labor stable ruling; i.e., $\beta_{\mathrm{H}}+h \theta$. For $\theta<\theta_{0}$, then, the bold line representing the court's equilibrium rulings coincides with $\beta_{\mathrm{H}}+h \theta$. Similarly, for $\theta>\theta_{l}, S(\theta)$ is entirely above $\mathrm{z}_{\mathrm{c}}$. In this subset of states the legislature is too pro-labor compared to the court, and thus the best choice for the court in such states is to enact the most "anti-labor" stable ruling; i.e., $\beta_{\mathrm{L}}+h \theta$. Proposition 1 below summarizes the preceding discussion.

Proposition 1. Assume that the realization of $\theta$ is public information. Then (i) $\gamma(\theta)=0$ for all $\theta$, and (ii) there exist $\theta_{0}, \theta_{1} \in[0,1], \theta_{0} \leq \theta_{1}$, such that:

$$
x_{c}^{P I}(\theta)=\left\{\begin{array}{ccc}
z_{L}\left(\theta ; \beta_{H}\right)=\beta_{H}+h \theta & \text { if } & \theta \leq \theta_{0} \\
z_{c} & \text { if } & \theta_{0} \leq \theta \leq \theta_{1} \\
z_{L}\left(\theta ; \beta_{L}\right)=\beta_{L}+h \theta & \text { if } & \theta \geq \theta_{1}
\end{array}\right.
$$


Specifically, $\theta_{0}=0$ for $z_{c}<\beta_{H}, \theta_{0}=1$ for $z_{c}>\beta_{H}+h$, and $\theta_{0}=\left(z_{c}-\beta_{H}\right) / h$ otherwise. $\theta_{1}$ is similarly defined, with $\beta_{L}$ in place of $\beta_{H}$.

The court is thus effectively constrained by the legislature for some realizations of public opinion when the set $K=\left\{\theta: \theta \leq \theta_{0} \vee \theta \geq \theta_{1}\right\}$ is non-empty. In other words, the court will be able to rule its preferred policy independently of public opinion only if this policy is both (i) pro-labor relative to the preferences of the critical legislator for a pro-labor coalition before a pro-labor electorate $\left(z_{\mathrm{c}}>z_{\mathrm{L}}\left(1 ; \beta_{\mathrm{L}}\right)=\beta_{\mathrm{L}}+h\right)$ and (ii) anti-labor relative to the preferences of the critical legislator for an anti-labor coalition before an anti-labor electorate $\left(z_{\mathrm{c}}<z_{\mathrm{L}}\left(0 ; \beta_{H}\right)=\beta_{\mathrm{H}}\right)$. Note that, as in Gely and Spiller (1990), this condition is more likely to be satisfied when there is significant dissent in congress (the critical legislators for a pro and anti-labor coalitions are far apart, $\beta_{L}<<\beta_{H}$ ) and legislators are not too responsive to public opinion ( $h$ is small).

Moreover, it follows from proposition 1 that, in general, the size of $K$ increases with $\beta_{L}$ and decreases with $\beta_{H}$. Thus, the set of realizations of public opinion for which the court is effectively constrained is always smaller the higher dissent in congress is. Proposition 1 does not imply, however, that the size of $K$ should be generically lower the less responsive legislators are to public opinion. To see this, note that the set of values of $\theta$ for which a sincere ruling by the court would not face an anti-labor reversal increases with $h$ (the court benefits, in this regard, from a more eager response of legislators to public opinion). Hence, the overall effect of legislators' responsiveness to public opinion on judicial independence depends on the relative position of the court in the policy space.

\section{Informative Judicial Lobbying}


The previous analysis showed that when the court is constrained for some (publicly known) preferences of the electorate, an increase in $\theta$ induces a more pro-labor ruling, and thus, a more pro-labor policy outcome in equilibrium. The first goal of this section is to show that, when policy-makers are uncertain about the realization of $\theta$, lobbying by the interest group restores the complete information mapping between the preferences of the electorate and policy outcomes. Suppose, for example, that the court would be constrained for some known preferences of the electorate. Then this result says that in the presence of lobbying, the court would be forced to adjust its behavior to reflect this constraint, even when it would be independent to rule according to its preferred policy given the prior beliefs of uninformed legislators. Similarly, suppose instead that the court would be independent to rule according to its preferred policy for some known preferences of the electorate. Then the court would indeed be able to rule freely in the presence of lobbying, even if it would be constrained given the prior beliefs of uninformed legislators. The result is stated formally in the next proposition (lemma 1 in the appendix provides a detailed characterization of equilibrium strategies):

Proposition 2. In the unique D1 equilibrium:

(i) Lobbying $\gamma(\theta)$ increases with $\theta$ in $K$, and does not change with $\theta$ in $\left[\theta_{0}, \theta_{l}\right]$;

(ii) Court's (stable) rulings $x_{\mathrm{c}}(a)$ satisfy $x_{\mathrm{c}}(\chi(\theta))=x_{c}^{P I}(\theta)$ for every $\theta$, where $x_{c}^{P I}(\theta)$ is given in proposition 1. In particular, the pro-labor tendency of rulings increases with the level of strikes; i.e., $x_{\mathrm{c}}(a)$ is increasing in a.

That is, in equilibrium the level of strikes will reflect the preferences of the electorate up to the extent that this information can influence a binding constraint for the court (and 
thus policy outcomes). We say, then, that strikes are effectively fully informative. As long as (informed) policy is responsive to the electorate's preferences, two union types facing different pro-labor dispositions of the electorate will always choose different levels of lobbying, allowing the reproduction of the complete information link between policies and the preferences of the electorate.

This does not imply, however, that the equilibrium will necessarily involve transmission of information. In fact, lobbying will be completely unresponsive to the preferences of the electorate if (and only if) the court is unconstrained for every possible realization of $\theta$. Conversely, there will be a complete separating equilibrium if (and only if) the court is constrained for every realization of public preferences. That is, only if the court's ideal policy is "extremely anti-labor" (i.e., $z_{c}<\beta_{L}$ ), or "extremely pro-labor" (i.e., $\left.z_{c}>\beta_{H}+h\right)$ by proposition 1 standards.

Proposition 2 allows us to study the response of the expected level of strikes and pro-labor rulings to changes in the composition of the legislature. Note that for our purposes changes in the composition of the legislature are relevant only to the extent that they affect the boundaries of the stable set of policies in the legislature, $z_{\mathrm{L}}\left(\theta ; \beta_{\mathrm{L}}\right)=\beta_{\mathrm{L}}+h \theta$ and $z_{\mathrm{L}}\left(\theta ; \beta_{\mathrm{H}}\right)=\beta_{\mathrm{H}}+h \theta$. Moreover, recall from the analysis of the symmetric information benchmark that the set of realizations of public opinion for which the court is effectively constrained is always smaller the higher dissent in congress is. That is, in general, the size of $K$ increases with $\beta_{L}$ and decreases with $\beta_{H}$. Proposition 2 then directly implies the following result, and its corollary:

Proposition 3. A pro-labor shift in the preferred policy of the critical legislator for a prolabor coalition $\beta_{L}$ (anti-labor coalition, $\beta_{H}$ ), increases the expected pro-labor tendency of 
the court' rulings level $E_{\theta}\left[x_{c}\right]$, and increases (reduces) the expected level of lobbying, $E_{\theta}$ $[\gamma]$.

Corollary 1. A mean preserving increase in the size of the set of stable policies in the legislature reduces the expected level of strikes in equilibrium.

Proposition 3 also has direct implications over the response of equilibrium outcomes to changes in court's preferences. First, it is clear from the previous analysis that the expected level of pro-labor rulings will increase following a pro-labor change in the court's preferences unless the court is constrained for every realization of $\theta$ both preceding and following this change. The change in the expected level of strikes is, however, ambiguous. ${ }^{7}$ Similarly, we know from the analysis of the symmetric information benchmark that the effect of legislators' responsiveness to public opinion on judicial decisions depends on the relative position of the court in the policy space. This implies that the relation between lobbying and the responsiveness of legislators to public opinion will also necessarily depend on the relative position of the court in the policy space.

\section{Empirical Implications}

The model has direct and empirically refutable implications. The first two implications are unique to this model. First, proposition 2 states that, in equilibrium, the "pro-labor" level of judicial decisions is increasing in the extent of the union's political activity. Thus, we should observe more "pro-labor" decisions when facing a higher level of union strikes. Second, the expected level of lobbying decreases the more effective the separation of powers between the court and the legislature is (i.e., the less responsive 
legislators' preferences are to the electorate's concerns, and the more divided congress is on the relevant issues). Specifically, as the corollary to proposition 3 points out, we expect the level of strikes to be decreasing in the amplitude of the set of stable policies in congress.

Our model also has more standard separation of powers empirical implications. As in most separation of powers models, Proposition 3 implies that the equilibrium level of "pro-labor" judicial decisions depends on the political composition of congress. In equilibrium, a more "pro-labor" congress will trigger more "pro-labor" decisions provided that the court is effectively constrained by congress. Thus, our model provides unique, as well, as standard empirical implications concerning separation of power models. The unique implications constitute direct tests of the signaling value of interest groups lobbying.

\section{The Politics of Labor Law Constitutional Interpretation in Argentina}

In this section we apply the model to study the politics of labor law constitutional interpretation in Argentina, and provide an evaluation of its empirical implications using data on strikes and supreme court's decisions between 1935 and 1998.

This case presents a natural application of the proposed framework. While formally independent, Argentina's supreme court has faced both implicit and explicit threats from the political powers, and has adjusted its behavior accordingly (see Helmke 2002, and Iaryczower, Spiller and Tommasi 2002). Moreover, the centralized control by unions of an institutional structure allowing the effective organization of large demonstrations have both broadened their scope of interest from industry level to national 
labor policies, and transformed organized demonstrations into instruments of political influence.

In this environment, the relevant assumptions we impose to the analysis translate into the following mild requirements. First, legislators are at least somewhat responsive to (but not perfectly informed about) the preferences of the electorate. ${ }^{8}$ Second, the union knows the cost of organizing public demonstrations, and this cost decreases the more intensely voters oppose anti-labor legislation. As we have shown in the previous section, under this assumption the observed level of protests will transmit valuable information about the preferences of the electorate to politicians in equilibrium, even if the union's slogans constitute a biased representation of society's interests.

\section{The Political Environment}

According to our framework, the relative position of the court with respect to the set of stable policies in the legislature is a major factor determining both court rulings and the level of lobbying. Our first task in defining the relevant independent variables, then, is to obtain an assessment of the distribution of preferences within congress along a prolabor/anti-labor policy space.

Throughout most of the twentieth century, Argentina had a strong presidential system with two dominant political parties (McGuire 1995; Jones 2002) characterized by a relatively sharp contrast in their stance with respect to labor policies and the regulation of organized labor (Rotondaro 1971; Torre 1983; Fernandez 1988; McGuire 1997). While all presidents have sought, to some extent, support from (at least some of) the unions, the strong association between unions and the Peronist party, and the Peronist/anti-Peronist division of Argentine society defined Argentina's political reality in the second part of 
the $20^{\text {th }}$ century. Relying on these facts, we classify each president (and its party in the legislature) as pro or anti-labor, and use this classification, along with the partisan composition of the legislature, to obtain an assessment of the pro-labor composition of the Argentine legislature.

We start by classifying Argentina's presidents between 1935 and 1997 as prolabor or anti-labor, following to the greater extent possible the "stylized facts" presented by previous studies. Presidents Farrel, Peron, and all Presidents who governed representing the Peronist Party (Campora, Lastiri, and Martinez in 1973- 1976, Menem between 1989 and 1999) were classified as pro-labor. President Frondizi (1958-1962) did not represent the Peronist party but was also classified as pro-labor. ${ }^{9}$ The remaining presidents (mainly military dictators and democratic presidents representing the UCR Party) were classified as anti-labor.

Taking this classification as given, we use parties' representation in the legislature to compute the distribution of preferences for the upper and lower chambers in each period $t, G_{t}^{U}(\cdot)$ and $G_{t}^{L}(\cdot)$. We assume, first, that legislative parties are perfectly cohesive, and that parties in the opposition have the opposite stance in the labor policy space than the president's party. The distribution of imputed preferences for legislators of chamber $j$ in period $t$ is in this case given by $G_{t}^{j}(x)=\omega_{t}^{j}$ for $0 \leq x<1$ and $G_{t}^{j}(1)=1$, where $\omega_{t}^{j}$ denotes the proportion of seats held by the anti-labor's party in chamber $j$ in period $t$ (we assume here that $\omega_{t}^{j}=1$ during periods of military interruptions to the democratic regime). We also let parties be imperfectly aligned with the president, and refer to this as a noisy representation of legislative parties. Specifically, for both the antilabor and the pro-labor party, we assume that the proportions of party members with ideal 
policy closer to the extreme anti-labor (0) and pro-labor (1) policies are given by a beta distribution $B(\alpha, \beta)$ with support in [0,1], for $\beta=1$ and $\alpha=0.1$ and $\alpha=0.2 .{ }^{10}$ With this assumption, then, the distribution of preferences of legislators in chamber $j$ in a democratic period $t$ is given by $G_{t}^{j}(x ; \alpha)=\omega_{t}^{j} \mathrm{~B}_{\alpha}(x)+\left(1-\omega_{t}^{j}\right)\left(1-\mathrm{B}_{\alpha}(1-x)\right) .{ }^{11}$

\section{Dependent Variables}

The dependent variables in our study are supreme court's pro-labor rulings and the amount of union strikes. We define the variable strikes as the number of strikes per year. ${ }^{12}$ Court rulings are those on labor and social security cases involving the constitutionality of government norms decided by the Argentine supreme court between 1935 and $1998 .^{13}$ Within this universe of cases, we define the categorical variable prolabor ruling to take the value of one (zero) if a court ruling (i) upholds a government norm during a pro-labor (anti-labor) presidency or (ii) challenges a government norm during an anti-labor (pro-labor) presidency.

\section{Independent Variables}

The pro-labor composition of the legislature is relevant for our purposes for two reasons. First, the appointment of a president's nominee to the supreme court requires the approval of the senate (by simple majority until 1994). Thus, the pro-labor composition of the senate affects directly the preferences of the court. To reflect the influence of the senate in a simple manner, we use the midpoint between the ideal point of the president and the median voter of the senate at the time of appointment as an estimate of the prolabor disposition of each justice. The pro-labor disposition of the court in each period,

pro-labor court, is then defined as the policy preference of the court's median justice. ${ }^{14}$ 
Second, the pro-labor compositions of the upper and lower chambers determine the set of stable policies in the legislature in any given period. A ruling is stable if it does not trigger a response by a pro or an anti-labor coalition in the legislature. Since until 1994 Argentina's Constitution allowed the legislature to enlarge the supreme court with a simple law, we will focus primarily on the critical legislators for simple majority rule in a bicameral legislature. These are denoted pro-labor critical and anti-labor critical and defined - for both the cohesive and noisy representations of legislative parties - as the minimum and maximum among the median legislators of the upper and lower chambers. ${ }^{15}$

The equilibrium level of pro-labor rulings and strikes depend, however, on the relative position of the court with respect to the set of stable policies in the legislature. Consider first the court. Justices will rule based solely on their preferences provided that their preferred policies are stable policies in the legislature, and will otherwise adjust their rulings so that these fall within the set of acceptable policies in the legislature. As a result, court's preferences will influence Justices' behavior directly only to the extent that the court is unconstrained. If instead an anti-labor court is constrained by the legislature, changes in the critical legislator for a pro-labor coalition - and not in court's preferences will influence court's decisions (we call this a pro-labor constraint). Similarly, if a prolabor court is constrained by the legislature, changes in the critical legislator for an antilabor coalition will influence court's decisions (we call this an anti-labor constraint). We then define the following variables. Pro-labor constraint equals pro-labor critical if an anti-labor court is constrained (i.e., if pro-labor court $<$ pro-labor critical) and zero otherwise. Similarly, anti-labor constraint equals anti-labor critical if a pro- labor court is 
constrained (if pro-labor court $>$ anti-labor critical) and zero otherwise. Finally, court unconstrained is defined as pro-labor court if the court is unconstrained, and zero otherwise.

The union, on the other hand, will only engage in lobbying if policy outcomes are responsive to lobbying efforts. This implies that the expected level of lobbying (strike activity) increases the more constrained the court is, and decreases (corollary 1) with the length of the set of stable policies in the legislature. We then define the variable binding as the distance between pro-labor court and the set of stable policies, and length as the distance between pro-labor critical and anti-labor critical.

We also define two control variables related to the political environment. First, we introduce the variable dictator, taking the value one in periods of interruptions to the democratic regime, to allow for possible direct effects of military governments on both rulings and strikes. ${ }^{16}$ Second, since the first administration of President Peron marked a defining moment in the relation of the polity to the judiciary (Iaryczower, Spiller and Tommasi 2002), in the organization of the labor movement, and in the consequent use of strikes (see Figure 2), we introduce the variable post-Peron, taking the value one for observations after President's Peron initial departure from office in September 1955.

$<$ Figure 2 about here $>$

\section{Estimation}

As indicated by proposition 2, court's pro-labor rulings are increasing in the observed level of strikes. The equilibrium level of strikes is in itself a response to the political environment and the relative positioning of the court in the (labor) policy space. It is not, however, a function of actual rulings by the court, which only happen after the level of 
strikes is observed. Specifically, for our main specification, the variables in the right hand side of the equation for pro-labor judicial decisions are given by court unconstrained, prolabor constraint, anti-labor constraint, post-Peron, and dictator. The variables in the right hand side of the strikes equation are given by length, binding, pro-labor court, postPeron, dictator, along with three lagged observations of the growth of GDP, included as controls.

Thus, the model we estimate is a triangular system of two equations. We then test the hypothesis that the variance-covariance matrix is diagonal with the data arranged on a case-based unit of analysis. Employing the Breusch and Pagan 1980 test (see Greene 2000,621 ), we conclude that the system is indeed fully recursive, and thus proceed to estimate it equation by equation (see Greene 2000, 678). Furthermore, since pro-labor ruling is a categorical variable, we use a logit model to estimate the conditional probability of a pro-labor ruling. Also, since the data for the number of strikes are only available yearly, we use the number of strikes in the year in which the supreme court decided the case in the court's decision equation. We use average annual values for the right hand side variables of the strikes equation.

Table 1 presents the results of the pro-labor rulings equation under the cohesive and noisy representations of the legislature for the complete sample (Model I), and for only democratic periods (Model II). ${ }^{17}$

$<$ Table 1 about here $>$

The results are consistent with the predictions of the model. As in separation of power models, the probability of a pro-labor ruling increases with the pro-labor disposition of unconstrained courts (court unconstrained) and when a binding constraint for a pro-labor 
court is relaxed (an increase in anti-labor constraint), ${ }^{18}$ or when a binding constraint for an anti-labor court is further tightened (an increase in a pro labor constraint). The coefficient of pro-labor constraint, however, is not statistically significant for the whole sample (Model I), although it is statistically significant at the $5 \%$ level for the democratic periods sample (Model II).

Moving towards the more unique implications of our model, we find that, consistent with proposition 2, pro-labor rulings increase with the level of strikes. This result stands for both the cohesive and noisy representations of the legislature, and for the whole or only the democratic period samples. In particular, setting the value of all variables at their sample average, a one standard deviation increase in the number of strikes - 152.6 and 180.4 for the complete and democratic samples- increases the probability of a pro-labor ruling by 12 to $13 \%$ for both samples and models.

We also find that the pro-labor tendency of court rulings increases during breakdowns of the democratic regime, and decreases following President Peron's first two terms in office. ${ }^{19}$

Table 2 presents the results of four exercises that complement the previous analysis. In Model III, we consider the model under the assumption that the relevant majority determining the constraints for the court is a supermajority of two thirds of the members of each chamber. We find that the coefficients of strikes and the preferences of unconstrained courts (court unconstrained) are statistically significant of the same order of magnitude as in Table 1. Political constraints with supermajority, however, seem to be less significant as explanatory variables for court's behavior. ${ }^{20}$

$<$ Table 2 about here $>$ 
Model IV considers an alternative method to capture the preferences of the court. While the appointment of the president's nominees to the supreme court requires the approval of the senate, it can be argued that the senate has only a formal role in this procedure. In this case, our measure of court's preferences would be improved by simply removing the influence of the senate. Thus, in Model IV we assume that the pro-labor stance of each justice equals that of the nominating president. ${ }^{21}$ According to the goodness of fit indicators, Model I performs better than Model IV. Model V considers the period prior to the first administration of President Peron, during which unions had more restrictive organizational capabilities. Thus, we do not expect strikes to be significantly informative about the preferences of a wide electorate. Consistent with this description, we find that although the estimated coefficients of strikes remain positive in all specifications, they are no longer statistically significant. Finally, Model VI considers the strategic defection hypothesis proposed by Helmke 2002. According to Helmke 2002, the political constraints faced by the Court in a given period can fall short of accounting for the entire range of incentives faced by the Court. The strategic defection hypothesis argues that Justices' behavior reflects not only the effect of current political constraints, but also their anticipation of the political constraints they will face in the future. To evaluate this hypothesis, we restrict the sample including only rulings decided one year before a change of president. The results are similar, although the precision of the estimates seems to improve, lending some support to this argument.

Table 3 presents the results obtained from the estimation of the strikes equation. The independent variables in Model I include length, binding, pro-labor court, postPeron, dictator, and three lagged observations of the growth of GDP, included as 
controls. The results are consistent with the model's empirical implications. First, according to proposition 3 (and its corollary), we expect the level of strikes to increase the more constrained the court is, and decrease with the size of the stable set (the "pooling" area). Table 3 supports these implications, as the coefficients of binding and length are of their predicted signs (positive and negative respectively) and all are statistically significant. ${ }^{22}$ Table 3 also shows that unions were less combative during military governments, and that (as Figure 2 anticipated) the organization of the labor movement since Peron resulted in a higher capacity of unions to engage in political demonstrations. ${ }^{23}$ In Model II, we also include the categorical variable end term, which takes the value of one in year $t$ if a president's term finishes either in $t$ or $t+1$. The estimated coefficient is positive, although it is statistically significant at the $10 \%$ level only for the noisy representations of legislative parties. Our results, then, provide some indication that unions strike more often in transitional periods.

\section{Conclusions}

We started this paper pointing to the scant empirical support for models of legislative lobbying. We provide here a framework that reconciles the theoretical literature of lobbying with the negative available evidence. The first contribution of the paper is then to show that the empirical work has been looking at the wrong impact of lobbying on policy. Rather than affecting policy by impacting on the nature of legislation, lobbying may be affecting policy via judicial decisions. Thus, judicial lobbying.

Since interest groups cannot directly lobby justices, however, the link between lobbying and court rulings can only be indirect: lobbying influences court rulings by affecting the political constraints faced by the court. Identifying this mechanism allows 
us to reconsider the determinants and effectiveness of lobbying in separation-of-powers systems. We show that a key factor in determining lobbying is the extent by which the information so generated can sway decisive majorities in the legislature to tighten the political constraints faced by an anti-interest group court, or relax the constraints faced by a pro-interest group court.

Our empirical results for the interactions among unions, courts, and the legislature in Argentina are consistent with this description. Argentine courts tend to side more with unions the more the unions strike. Unions, in turn, strike more when courts face a more unified legislature. It is in these situations that unions' lobbying makes the legislature more pro-labor, triggering, then, more pro-union judicial decisions. Our paper, then, suggests that analyses of lobbying should pay closer attention to the actual nature of the policy making process, and in particular, to the interaction of the bureaucracy, the courts and the legislature. 


\section{Appendix}

Definition (Ramey 1996) Fix a sequential equilibrium $\Gamma$, and denote the payoff in $\Gamma$ of a type- $\theta$ union by $U(\theta)$. Fix an off-the-equilibrium-path action a by the union; i.e., a $\notin$ $\chi([0,1])$, and suppose there is a nonempty set $X^{\prime} \subset X$ such that: for all $\theta \notin X^{\prime}$ there exists $\theta^{\prime} \in X^{\prime}$ such that $U(a, x, \theta) \geq U(\theta)$ implies $U\left(a, x, \theta^{\prime}\right)>U\left(\theta^{\prime}\right)$. Then the equilibrium is said to violate criterion D1 unless it is the case that the support of $F(\theta \mid a)$ is included in $X^{\prime} . A$ sequential equilibrium is a D1 equilibrium if it does not violate criterion D1 for any a $\notin$ $\gamma([0,1])$

Lemma 1. Coupled with beliefs satisfying Bayes' rule, the following strategies constitute a sequential equilibrium: (i) court's strategy $x_{c}(a)$ is defined by $x_{c}(a)=x_{c}^{P I}\left(\gamma^{-1}(a)\right)$ for all a such that $\gamma^{-1}(a) \in K$, and $x_{\mathrm{c}}\left(\gamma^{0}\left(\theta_{0}\right)\right)=z_{\mathrm{c}}$, where $x_{c}^{P I}(\cdot), \theta_{0}$ and $\theta_{1}$ are given in proposition 1; and (ii) union's strategy $\chi(\cdot)$ is defined by:

$$
\gamma(\theta)=\left\{\begin{array}{ccc}
\Lambda_{H} \ln \left(\frac{k}{k-\theta}\right)+h^{2} \theta \equiv \gamma^{0}(\theta) & \text { if } & 0 \leq \theta \leq \theta_{0} \\
\gamma^{0}\left(\theta_{0}\right) & \text { if } & \theta_{0} \leq \theta \leq \theta_{1} \\
\gamma^{0}\left(\theta_{0}\right)+\Lambda_{L} \ln \left(\frac{k-\theta_{1}}{k-\theta}\right)+h^{2}\left(\theta-\theta_{1}\right) \equiv \gamma^{1}(\theta) & \text { if } & \theta_{1} \leq \theta \leq 1
\end{array}\right.
$$

where $\Lambda_{s} \equiv\left[h\left(1-\beta_{s}\right)-h^{2} k\right]$ for $s=H, L$.

Proof of Lemma 1. First note that if beliefs satisfy Bayes' rule, then (i) for all $a$ such that $\gamma^{-1}(a) \in K, f(\theta \mid a)=1$ if $\theta=\gamma^{-1}(a)$, and $f(\theta \mid a)=0$ if $\theta \neq \gamma^{-1}(a)$, and (ii)for $a=\gamma^{0}\left(\theta_{0}\right), f(\theta \mid a)$ $=f(\theta) /\left[F\left(\theta_{l}\right)-F\left(\theta_{0}\right)\right]$ if $\theta \in\left[\theta_{0}, \theta_{l}\right]$, and $f(\theta \mid a)=0$ otherwise. Hence it follows directly 
from proposition 1 that the Court's proposed strategy specifies is a best response given these beliefs. It remains to show the optimality of union's strategy given $f(\mid a)$ and $x_{c}()$. To do so it is enough - by the revelation principle - to consider direct mechanisms in which every type has the incentive to make truthful announcements. Suppose first that $\theta_{0}>0$. Our initial step is to show that if the restriction of the union strategy to $\left[0, \theta_{0}\right]$ is given by $\gamma^{0}(\theta)$, as defined above, then a union of type $\theta \leq \theta_{0}$ does not have the incentive to misrepresent its type by claiming that its type is $\theta^{\prime} \in\left[0, \theta_{0}\right], \theta^{\prime} \neq \theta$. To see this, consider an arbitrary strategy $\tilde{\gamma}(\theta)$ and its restriction to $\left[0, \theta_{0}\right]$. Truth telling is then optimal for $\theta$ in this range only if:

$$
\theta=\underset{\hat{\theta} \in\left[0, \theta_{0}\right]}{\arg \max } U(\hat{\theta}, \theta) \equiv u_{u}\left(z_{L}\left(\hat{\theta} ; \beta_{H}\right)\right)-C(\widetilde{\gamma}(\hat{\theta}), \theta)=\left\{-\frac{1}{2}\left(1-\beta_{H}-h \hat{\theta}\right)^{2}-\widetilde{\gamma}(\hat{\theta})(k-\theta)\right\}
$$

Note that the FOC for a maximum at $\theta$ can be written as:

$$
\frac{\partial \widetilde{\gamma}(\theta)}{\partial \hat{\theta}}=\left[\frac{\partial u_{u}\left(z_{L}\left(\theta ; \beta_{H}\right)\right) / \partial x}{\partial C(\widetilde{\gamma}(\theta), \theta) / \partial a}\right] \frac{\partial z_{L}\left(\theta ; \beta_{H}\right)}{\partial \hat{\theta}}=\frac{\left[1-\beta_{H}-h \theta\right] h}{k-\theta}
$$

From this it follows immediately that $\widetilde{\gamma}(\theta)$ is strictly increasing in $\theta$ in $\left[0, \theta_{0}\right]$ (the second order condition, assuring that $\tilde{\gamma}(\theta)$ is incentive compatible across $\left[0, \theta_{0}\right]$, follows from the assumption that $C_{a \theta}(a, \theta)<0$. See Fudenberg and Tirole 1998, pp. 262). Moreover, for the functional forms specified, we can obtain:

$$
\tilde{\gamma}(\theta)=\int_{0}^{\theta} \frac{h\left(1-\beta_{H}\right)-h^{2} s}{k-s} d s=\left[h\left(1-\beta_{H}\right)-h^{2} k\right] \ln \left(\frac{k}{k-\theta}\right)+h^{2} \theta=\gamma^{0}(\theta)
$$

Note that we have made use of the fact that $\gamma(0)=0$. For suppose not; that is, suppose $\gamma(0)=\underline{a}>0$, and consider a deviation by type $\theta=0$ to action $a=0$. Equilibrium policy 
following the observation of lobbying level $\underline{a}=\min \gamma([0,1])$ results in the complete information policy corresponding to the lower type in the distribution; i.e., $x_{c}(\underline{a})=$ $x_{c}(\theta=0)$. But after a deviation, uninformed agents will respond with strategies that are optimal given some beliefs with support in $[0,1]$. Then policy following a deviation cannot possibly be worst for the union than equilibrium policy. Hence, the deviation is profitable for type 0 , since it reduces costs but can't adversely affect outcomes.

An identical argument shows that if $\theta_{1}<1$, a $\theta$-type union, $\theta \geq \theta_{1}$, does not have an incentive to play $\gamma\left(\theta^{\prime \prime}\right)$ for $\theta^{\prime \prime} \neq \theta, \theta^{\prime \prime} \in\left[\theta_{1}, 1\right]$. Furthermore, it follows from the previous argument that a type $\theta<\theta_{0}$ does not have an incentive to play $\gamma^{P}=\gamma\left(\theta_{0}\right)$; i.e., every type $\theta \in\left[0, \theta_{0}\right)$ prefers $\left(\gamma^{0}(\theta), z_{L}\left(\theta ; \beta_{H}\right)\right)$ to $\left(\gamma^{P}, z_{\mathrm{c}}\right)$. Similarly, when $\theta_{1} \in(0,1)$, there is no type $\theta>\theta_{l}$ with an incentive to play $\gamma^{P}=\gamma\left(\theta_{l}\right)$. We continue by showing that when $0<\theta_{0}<\theta_{1}<1$, no type in $\theta \in\left[0, \theta_{0}\right]$ has an incentive to play $\gamma\left(\theta^{\prime}\right)$ for $\theta^{\prime} \in\left[\theta_{1}, 1\right]$ (and the opposite). That is, we want to show that $u\left(z_{L}\left(\theta ; \beta_{H}\right)\right)-C(\gamma(\theta), \theta) \geq u\left(z_{L}\left(\theta^{\prime} ; \beta_{L}\right)\right)-$ $C\left(\gamma^{\prime}\left(\theta^{\prime}\right), \theta\right)$ for $\theta \leq \theta_{0}, \theta^{\prime} \geq \theta_{l}$. Since $\theta \leq \theta_{0}$ prefers $\left(\gamma^{0}(\theta), z_{L}\left(\theta ; \beta_{H}\right)\right)$ to $\left(\gamma^{P}, z_{c}\right)=\left(\gamma^{\prime}\left(\theta_{l}\right)\right.$, $\left.z_{L}\left(\theta_{1} ; \beta_{L}\right)\right)$, we have, for $\theta \leq \theta_{0}$ :

$$
u_{u}\left(z_{L}\left(\theta ; \beta_{H}\right)\right)-C\left(\gamma^{0}(\theta), \theta\right) \geq u\left(z_{L}\left(\theta_{1} ; \beta_{L}\right)\right)-C\left(\gamma^{1}\left(\theta_{1}\right), \theta\right)
$$

Also, we know that $\theta^{\prime \prime} \geq \theta_{I}$ prefers $\left(\gamma^{\prime}\left(\theta^{\prime \prime}\right), z_{L}\left(\theta^{\prime} ; \beta_{L}\right)\right)$ to $\left(\gamma^{\prime}\left(\theta^{\prime}\right), z_{L}\left(\theta^{\prime} ; \beta_{L}\right)\right)$ for $\theta^{\prime} \geq \theta_{l}$, $\theta^{\prime \prime} \neq \theta^{\prime}, \theta^{\prime \prime} \geq \theta_{1}$. In particular, with $\theta^{\prime \prime}=\theta_{1}$, this implies, for $\theta^{\prime}>\theta_{1}$ :

$$
u\left(z_{L}\left(\theta_{1} ; \beta_{L}\right)\right)-C\left(\gamma^{1}\left(\theta_{1}\right), \theta_{1}\right) \geq u\left(z_{L}\left(\theta^{\prime} ; \beta_{L}\right)\right)-C\left(\gamma^{1}\left(\theta^{\prime}\right), \theta_{1}\right)
$$

Now by (2), for $\theta \leq \theta_{1}$,

$$
u\left(z_{L}\left(\theta^{\prime} ; \beta_{L}\right)\right)-u\left(z_{L}\left(\theta_{1} ; \beta_{L}\right) \leq \int_{\gamma^{1}\left(\theta_{1}\right)}^{\gamma^{1}\left(\theta^{\prime}\right)} \frac{\partial C\left(a, \theta_{1}\right) d a}{\partial a} \leq \int_{\gamma^{1}\left(\theta_{1}\right)}^{\gamma^{1}\left(\theta^{\prime}\right)} \frac{\partial C(a, \theta) d a}{\partial a}\right.
$$


so that for $\theta \leq \theta_{1} \leq \theta^{\prime}$,

$$
u\left(z_{L}\left(\theta^{\prime} ; \beta_{L}\right)\right)-C\left(\gamma^{1}\left(\theta^{\prime}\right), \theta\right) \leq u\left(z_{L}\left(\theta_{1} ; \beta_{L}\right)\right)-C\left(\gamma^{1}\left(\theta_{1}\right), \theta\right)
$$

The result then follows from (1) and (3). In addition, (3) also shows that any type in the pool $\left[\theta_{0}, \theta_{l}\right]$ prefers the pool than to announce $\theta^{\prime} \geq \theta_{l}$. A similar argument establishes that when $0<\theta_{0}<\theta_{1}<1$, no type $\theta \in\left[\theta_{1}, 1\right]$ has an incentive to play $\gamma\left(\theta^{\prime}\right)$ for $\theta^{\prime} \in\left[0, \theta_{0}\right]$, and that no type in the pool prefers to announce $\theta^{\prime} \leq \theta_{0}$. Finally, it is easy to see that $\gamma$ can have no discontinuities at $\gamma^{0}\left(\theta_{0}\right)$, for in this case there would exist $\theta<\theta_{0}$ sufficiently close to $\theta_{0}$ for which a deviation by $\theta_{0}$ would be profitable (involving a marginal loss in policy, but a discrete reduction in lobbying costs). Similarly, it can be shown that when $\theta_{1}<1, \gamma\left(\theta_{1}\right)=\gamma^{0}\left(\theta_{0}\right)$ when $\theta_{0}>0$. That $\gamma\left(\theta_{l}\right)=0$ if $\theta_{0}=0$, as we argued above, is covered in the claim that $\gamma(0)=0$.

Proof of Proposition 2. That there exists an equilibrium where (i) and (ii) hold follow immediately from Lemma 1. It remains to show that this is indeed the unique equilibrium satisfying criterion D1. So let $\widetilde{\Pi} \equiv\left(\widetilde{\gamma}, \widetilde{x}_{c}, \widetilde{f}(\cdot \mid a)\right)$ be an equilibrium satisfying criterion D1. We will show that if $\theta_{0}>0$, then $\tilde{\gamma}(\theta)=\gamma^{0}(\theta) \quad \forall \theta \in\left[0, \theta_{0}\right]$. The same argument can then be applied to show that if $\theta_{1}<1$, then $\tilde{\gamma}(\theta)=\gamma^{1}(\theta) \quad \forall \theta \in\left[\theta_{1}, 1\right]$.

From the proof of lemma 1 , we only need to show that $\tilde{\gamma}(\theta)$ is strictly increasing in $\left[0, \theta_{0}\right]$. So suppose that this is not the case. That is, for $a>0$, let $\widetilde{\Gamma}^{-1}(a)$ denote the inverse image set of $a$ under $\tilde{\gamma}$, and suppose that there exists an $a^{P}>0$ such that $\widetilde{X}_{0}^{P} \equiv\left\{\theta \in \widetilde{\Gamma}^{-1}\left(a^{P}\right): 0 \leq \theta \leq \theta_{0}\right\}$ is not a singleton. Since $\widetilde{\gamma}$ must be monotonically (weakly) 
increasing, $\widetilde{X}_{0}^{P}$ must then be an interval $[\underline{\theta}, \bar{\theta}] \subseteq\left[0, \theta_{0}\right]$. Let $x_{L}\left(\widetilde{f}(\cdot \mid a) ; \beta_{L}\right)$, and $x_{L}\left(\tilde{f}(\cdot \mid a) ; \beta_{H}\right)$ denote the preferred policies of the critical legislators $\beta_{L}$ and $\beta_{H}$ given beliefs $\tilde{f}(\cdot \mid a)$. As in the case with complete information, we can now show that the set of stable policies is given by $S_{\tilde{f}(\cdot \mid a)}=\left(x_{L}\left(\tilde{f}(\cdot \mid a) ; \beta_{L}\right), x_{L}\left(\tilde{f}(\cdot \mid a) ; \beta_{H}\right)\right) \equiv(\underline{s}(a), \bar{s}(a))$. But if $\widetilde{X}_{0}^{P}=[\underline{\theta}, \bar{\theta}] \subseteq\left[0, \theta_{0}\right]$, then Bayes' rule and the full support assumption imply that $\tilde{f}\left(\theta \mid a^{P}\right)>0$ for every $\theta \in[\underline{\theta}, \bar{\theta}]$ and $\tilde{f}\left(\theta \mid a^{P}\right)=0$ otherwise. This in turn implies that $z_{L}\left(\underline{\theta} ; \beta_{H}\right)<\bar{s}\left(a^{P}\right)<z_{L}\left(\bar{\theta} ; \beta_{H}\right)$. And since $\bar{\theta} \leq \theta_{0}=\left(z_{c}-\beta_{H}\right) / h$, then $z_{L}\left(\bar{\theta} ; \beta_{H}\right)<z_{c}$. Thus the constraint is binding for the Court, and $\tilde{x}_{c}\left(a^{P}\right)=\bar{s}\left(a^{P}\right)$. Next, choose $\theta<\bar{\theta}$ sufficiently close to $\bar{\theta}$ so that $\bar{s}\left(a^{P}\right)<z_{L}\left(\theta ; \beta_{H}\right)$. Since by assumption $C_{a \theta}<0$, the slope of a union's indifference curve in the $(a, x)$ space is decreasing in the type $\theta$, and we can always find a pair $\left(a^{*}, x_{c}{ }^{*}\right)$ such that $U\left(a^{*}, x_{c}{ }^{*}, \theta\right)>U\left(a^{P}, \bar{s}\left(a^{P}\right), \theta\right)(1)$, and for any $\theta^{\prime}<\theta$ $U\left(a^{*}, x_{c}{ }^{*}, \widetilde{\theta}\right)<U\left(a^{P}, \bar{s}\left(a^{P}\right), \widetilde{\theta}\right) \forall \widetilde{\theta} \leq \theta^{\prime}$ (2). Furthermore, we can as well find one such pair for $x_{c}{ }^{*}<z_{L}\left(\theta ; \beta_{H}\right)$. Suppose first that $a \in \operatorname{range}(\tilde{\gamma})$. Since $\tilde{\gamma}$ is an equilibrium, this implies that $\widetilde{x}_{c}\left(a^{*}\right)<x_{c} *$ (IC for $\theta$ ). But then (2) implies that $\tilde{\gamma}(\widetilde{\theta}) \neq a * \forall \widetilde{\theta} \leq \theta$. Then $\operatorname{supp}\left\{\tilde{f}\left(\cdot \mid a^{*}\right)\right\} \subset[\theta, \bar{\theta}]$ and hence $\widetilde{x}_{c}\left(a^{*}\right) \geq z_{L}\left(\theta ; \beta_{H}\right)$, which is a contradiction. Now suppose instead that $a \notin \operatorname{range}(\widetilde{\gamma})$. Then if $U\left(a^{*}, x_{c}, \widetilde{\theta}\right) \geq U\left(a^{P}, \bar{s}\left(a^{P}\right), \widetilde{\theta}\right)$ for $\widetilde{\theta} \leq \theta,(2)$ implies that $x_{c}>x_{c}{ }^{*}$, so that, by (1), $U\left(a^{*}, x_{c}, \theta\right)>U\left(a^{P}, \bar{s}\left(a^{P}\right), \theta\right)$. Thus criterion D1 requires $\operatorname{supp}\left\{\tilde{f}\left(\theta \mid a^{*}\right)\right\} \subseteq[\theta, \bar{\theta}]$. But in this case type $\bar{\theta}$ has an incentive to deviate from the proposed equilibrium behavior.

Q.E.D. 


\section{References}

Ainsworth, Scott 1993. "Regulating Lobbyists and Interest Group Influence." The Journal of Politics 55 (February): 41-56

Austen-Smith, David 1993. "Information and Influence: Lobbying for Agendas and Votes." American Journal of Political Science 37 (August): 799-833.

Ansolabehere, Stephen D., John M. de Figueiredo, and James M. Snyder 2003. "Why Is There So Little Money in Politics?" Journal of Economic Perspectives 17(Winter): 105-130.

Banks, Jeffrey S., and Joel Sobel 1987. "Equilibrium Selection in Signaling Games." Econometrica 55 (May): 647-661.

Baron, David 1994. "Spatial Electoral Competition and Campaign Contributions with Informed and Uninformed Voters." American Political Science Review 88 (March): 3347.

Bergara, Mario, Barak D. Richman, and Pablo T. Spiller 2003. "Modeling Supreme Court Strategic Decision Making: The Congressional Constraint." Legislative Studies Quarterly 28 (May): 247-280.

Bernheim, Douglas 1994. "A Theory of Conformity." Journal of Political Economy 102 (October): 841-877.

Cho, Inn Koo, and David M. Kreps 1987. "Signaling Games and Stable Equilibria." Quarterly Journal of Economics 102 (May): 179-221.

de Figuereido, John M. 2002. "Lobbying and Information in Politics." Business and Politics 4 (2): 125-129 
Denzau, Arthur T., and Michael C. Munger 1986. "Legislators and Interest Groups: How Unorganized Interests Get Represented.” American Political Science Review 80 (March): 89-106.

Fernandez, Arturo 1988. Las Practicas Sociopoliticas del Sindicalismo (1955-1985). Buenos Aires: Centro Editor de America Latina.

Fudenberg, Drew, and Jean Tirole 1998. Game Theory, 6th ed. Cambridge: The MIT Press. Gely, Rafael and Pablo T. Spiller 1990. “A Rational Choice Theory of Supreme Court Statutory Decisions with Applications to the State Farm and Grove City Cases." Journal of Law, Economics and Organization 6 (Fall): 263-300

Gely, Rafael and Pablo T. Spiller 1992. "The political economy of supreme court constitutional decisions: The case of Roosevelt's court-packing plan." International Review of Law and Economics 12 (March): 45-67.

Greene, William 2000. Econometric Anaysis, $4^{\text {th }}$. ed. New Jersey: Prentice Hall.

Helmke, Gretchen 2002. "The Logic of Strategic Defection: Court-Executive Relations in Argentina Under Dictatorship and Democracy.” American Political Science Review 96 (June): 291-303.

Iaryczower, Matias 2005. “Contestable Leaderships: Party Discipline and Vote Buying in Legislatures.” Typescript. University of California, Los Angeles.

Iaryczower, Matias, Pablo T. Spiller, and Mariano Tommasi 2002. "Judicial Independence in Unstable Environments." American Journal of Political Science 46 (October): 699716. 
Jones, Mark 2002. "Explaining the High Level of Party Discipline in the Argentine Congress." In Legislative Politics in Latin America, ed. Scott Morgenstern and Benito Nacif. Cambridge: Cambridge University Press.

Lohmann, Susanne 1995. "Information, Access and Contributions: A Signaling Model of Lobbying.” Public Choice 85 (December): 267-284

McGuire, James 1995. "Political Parties and Democracy in Argentina." In Building Democratic Institutions: Party Systems in Latin America, ed. Scott Mainwaring and Timothy Scully. Stanford: Stanford University Press.

McGuire, James 1997. Peronism without Peron: unions, Parties, and Democracy in Argentina. Stanford: Stanford University Press.

Nueva Mayoria 2001. “Argentina: Conflictos Laborales desde 1980.” < http://www.nuevamayoria.com/ES/ >

O’Donnell, Guillermo 2000. “Argentina, Domestic Violence and Economic Data, 19551972”. [Computer File]. ICPSR Version. Ann Arbour MI: Inter-University Consortium for Political and Social Research [Distributor], 2000.

Ramey, Garey 1996. "D1 Signaling Equilibria with Multiple Signals and a Continuum of Types." Journal of Economic Theory 69 (May): 508-531.

Rasmusen, Eric 1993. "Lobbying when the Decisión Maker can Acquire Independent Information.” Public Choice 77 (December): 899-913

Rotondaro, Ruben 1971. Realidad y Cambio en el Sindicalismo. Buenos Aires: Pleamar Segal, Jeffrey A. 1997. "Separation-of-Power Games in the Positive Theory of Congress and Courts." American Political Science Review 91 (March): 28-44. 
Snyder, James M. Jr. 1990. “Campaign Contributions as Investments: The U.S House of Representatives, 1980-1986." Journal of Political Economy 98 (December): 11951227.

Snyder, James M. Jr. 1991. “On Buying Legislatures.” Economics and Politics 3 (July): 93109.

Snyder, James M. Jr. 1992. "Long Term Investing in Politicians, or, Give Early, Give Often.” Journal of Law and Economics 35 (April): 15-43.

Stratmann, Thomas 1992. "Are Contributors Rational? Untangling Strategies of Political Action Committees." Journal of Political Economy 100 (June): 647-664.

Stratmann, Thomas 1995. "Campaign Contributions and Congressional Voting. Does the Timing of the Contributions Matter? Review of Economics and Statistics 77 (February): 127-136.

Stratmann, Thomas 1996. "How Reelection Constituencies Matter: Evidence from Political Action Committees' Contributions and Congressional Voting." Journal of Law and Economics 39 (October): 603-635.

Toma, Eugenia F. 1991. "Congressional Influence and the Supreme Court: The Budget as Signaling Device.” Journal of Legal Studies 20 (January): 131-146.

Torre, Juan Carlos 1983. Los Sindicatos en el Gobierno, 1973-1976. Buenos Aires, Centro Editor de America Latina. 


\begin{tabular}{|c|c|c|c|c|c|c|}
\hline \multirow[t]{2}{*}{ Variable } & \multicolumn{3}{|c|}{ Model I } & \multicolumn{3}{|c|}{ Model II } \\
\hline & Cohesive & Noisy (0.1) & Noisy (0.2) & Cohesive & Noisy (0.1) & Noisy (0.2) \\
\hline Strikes & $\begin{array}{c}0.003^{* * *} \\
(0.001)\end{array}$ & $\begin{array}{c}0.003^{* * *} \\
(0.001)\end{array}$ & $\begin{array}{c}0.003^{* * *} \\
(0.001)\end{array}$ & $\begin{array}{c}0.003^{* *} \\
(0.002)\end{array}$ & $\begin{array}{l}0.003^{* *} \\
(0.001)\end{array}$ & $\begin{array}{c}0.003^{* *} \\
(0.001)\end{array}$ \\
\hline Court unconstrained & $\begin{array}{c}1.437^{\star * *} \\
(0.493)\end{array}$ & $\begin{array}{c}2.829^{*} \\
(1.497)\end{array}$ & n.o. & $\begin{array}{c}1.856^{\star \star *} \\
(0.551)\end{array}$ & $\begin{array}{c}3.799 * * \\
(1.591)\end{array}$ & n.o. \\
\hline Pro-labor constraint & $\begin{array}{l}1.144 \\
(0.734)\end{array}$ & $\begin{array}{l}1.128 \\
(0.820)\end{array}$ & $\begin{array}{l}1.147 \\
(0.968)\end{array}$ & $\begin{array}{c}2.414 \text { ** } \\
(1.135)\end{array}$ & $\begin{array}{c}2.955^{* *} \\
(1.299)\end{array}$ & $\begin{array}{c}3.626 \text { ** } \\
(1.568)\end{array}$ \\
\hline Anti-labor constraint & n.o. & $\begin{array}{c}1.565^{* * *} \\
(0.496)\end{array}$ & $\begin{array}{c}1.927^{* * *} \\
(0.610)\end{array}$ & n.o. & $\begin{array}{c}2.307^{\star \star * *} \\
(0.627)\end{array}$ & $\begin{array}{c}3.126^{* * *} \\
(0.850)\end{array}$ \\
\hline Post-Peron & $\begin{array}{c}-1.558^{* * *} \\
(0.506)\end{array}$ & $\begin{array}{c}-1.449^{* * *} \\
(0.462)\end{array}$ & $\begin{array}{c}-1.328^{* * *} \\
(0.473)\end{array}$ & $\begin{array}{c}-1.891 \text { *** } \\
(0.620)\end{array}$ & $\begin{array}{c}-1.728^{* * *} \\
(0.554)\end{array}$ & $\begin{array}{c}-1.402^{* * *} \\
(0.554)\end{array}$ \\
\hline Dictator & $\begin{array}{c}1.064 \text { ** } \\
(0.541)\end{array}$ & $\begin{array}{c}1.027^{* *} \\
(0.480)\end{array}$ & $\begin{array}{c}1.083^{* *} \\
(0.500)\end{array}$ & & & \\
\hline Constant & $\begin{array}{c}-0.346 \\
(0.405)\end{array}$ & $\begin{array}{c}-0.449 \\
(0.452)\end{array}$ & $\begin{array}{c}-0.637 \\
(0.548)\end{array}$ & $\begin{array}{l}-0.460 \\
(0.423)\end{array}$ & $\begin{array}{r}-0.847^{*} \\
(0.509)\end{array}$ & $\begin{array}{c}-1.470 \text { ** } \\
(0.703)\end{array}$ \\
\hline \multirow[t]{2}{*}{ Database } & \multicolumn{3}{|c|}{ Standard, $N=315$} & \multicolumn{3}{|c|}{ Democracy, $N=178$} \\
\hline & \multicolumn{6}{|c|}{ Goodness of Fit } \\
\hline Prob > LR chi ${ }^{2}$ & 0.000 & 0.000 & 0.000 & 0.001 & 0.001 & 0.000 \\
\hline Prob > Pearson chi ${ }^{2}$ & 0.019 & 0.018 & 0.025 & 0.033 & 0.027 & 0.029 \\
\hline Area u / ROC curve & 0.673 & 0.674 & 0.676 & 0.682 & 0.698 & 0.709 \\
\hline Correctly Classified & 0.616 & 0.648 & 0.648 & 0.607 & 0.646 & 0.674 \\
\hline
\end{tabular}




\begin{tabular}{|c|c|c|c|c|c|c|c|c|}
\hline \multirow{3}{*}{ Variable } & \multicolumn{2}{|c|}{ Model III } & \multicolumn{2}{|c|}{ Model IV } & \multicolumn{2}{|c|}{ Model V } & \multicolumn{2}{|c|}{ Model VI } \\
\hline & \multicolumn{2}{|c|}{$\begin{array}{c}\text { Supermajority for } \\
\text { Stable Set }\end{array}$} & \multicolumn{2}{|c|}{$\begin{array}{l}\text { Senate not involved } \\
\text { in S.C. appointments }\end{array}$} & \multicolumn{2}{|c|}{ Pre-Peron } & \multicolumn{2}{|c|}{ Strategic Defection } \\
\hline & Cohesive & Noisy (0.1) & Cohesive & Noisy (0.1) & Cohesive & Noisy (0.1) & Cohesive & Noisy (0.1) \\
\hline Strikes & $\begin{array}{l}0.004^{* \star *} \\
(0.001)\end{array}$ & $\begin{array}{c}0.003^{* *} \\
(0.001)\end{array}$ & $\begin{array}{c}0.004^{* \star *} \\
(0.001)\end{array}$ & $\begin{array}{c}0.003^{* * *} \\
(0.001)\end{array}$ & $\begin{array}{l}0.023 \\
(0.025)\end{array}$ & $\begin{array}{l}0.025 \\
(0.025)\end{array}$ & $\begin{array}{c}0.004^{* *} \\
(0.002)\end{array}$ & $\begin{array}{c}0.004^{\star *} \\
(0.002)\end{array}$ \\
\hline Court unconstrained & $\begin{array}{l}1.854 \text { *** } \\
(0.549)\end{array}$ & $\begin{array}{l}1.951^{* * *} \\
(0.415)\end{array}$ & $\begin{array}{l}1.066^{* * *} \\
(0.379) \\
0.959\end{array}$ & $\begin{array}{r}\text { n.o. } \\
0.735\end{array}$ & $\begin{array}{c}2.282^{* * *} \\
(0.708) \\
2.129^{* *}\end{array}$ & $\begin{array}{c}\text { n.o. } \\
2.190 \text { ** }\end{array}$ & $\begin{array}{l}1.920 * * * \\
(0.615)\end{array}$ & $\begin{array}{c}3.785^{* *} \\
(1.622) \\
3.249^{* *}\end{array}$ \\
\hline Pro-labor constraint ${ }^{a}$ & & & (0.718) & $(0.749)$ & (0.916) & $(1.011)$ & & (1.414) \\
\hline Anti-labor constraint & n.o. & $\begin{array}{l}0.481 \\
(0.367)\end{array}$ & n.o. & $\begin{array}{l}1.210 * * * \\
(0.452)\end{array}$ & n.o. & $\begin{array}{c}2.486 \text { *** } \\
(0.760)\end{array}$ & n.o. & $\begin{array}{c}2.523 \text { *** } \\
(0.744)\end{array}$ \\
\hline $\begin{array}{c}\text { Post-Peron } \\
\text { Dictator }\end{array}$ & $\begin{array}{l}-1.942 * * * \\
(0.602)\end{array}$ & $\begin{array}{c}-1.205^{* *} \\
(0.530)\end{array}$ & $\begin{array}{l}-1.414 \\
(0.482) \\
0.675 \\
(0.443)\end{array}$ & $\begin{array}{l}-1.327^{* * *} \\
(0.452) \\
0.678 \\
(0.435)\end{array}$ & & & $\begin{array}{c}-1.751 \text { *** } \\
(0.621) \\
1.666 * * \\
(0.714)\end{array}$ & $\begin{array}{c}-1.574^{* * *} \\
(0.579) \\
1.941^{* * *} \\
(0.717)\end{array}$ \\
\hline Constant & $\begin{array}{l}-0.540 \\
(0.429) \\
\end{array}$ & $\begin{array}{r}-0.825^{*} \\
(0.432) \\
\end{array}$ & $\begin{array}{l}-0.136 \\
0.36316 \\
\end{array}$ & $\begin{array}{c}-0.188 \\
(0.427) \\
\end{array}$ & $\begin{array}{l}-1.304 \\
(0.924) \\
\end{array}$ & $\begin{array}{c}-1.555 \\
(0.975) \\
\end{array}$ & $\begin{array}{c}-0.649 \\
(0.519) \\
\end{array}$ & $\begin{array}{c}-1.080 * * \\
(0.642) \\
\end{array}$ \\
\hline \multirow[t]{2}{*}{ Database } & \multicolumn{2}{|c|}{ Democracy, $N=172$} & \multicolumn{2}{|c|}{ Standard, $N=315$} & \multicolumn{2}{|c|}{ Pre-Peron, $N=65$} & \multicolumn{2}{|c|}{$\begin{array}{l}1+\text { Year for a change } \\
\text { of President, } N=210\end{array}$} \\
\hline & \multicolumn{8}{|c|}{ Goodness of Fit } \\
\hline Prob > LR chi ${ }^{2}$ & 0.001 & 0.000 & 0.000 & 0.000 & 0.003 & 0.005 & 0.000 & 0.000 \\
\hline Prob $>$ Pearson chi $^{2}$ & 0.039 & 0.144 & 0.024 & 0.015 & 0.104 & 0.088 & 0.073 & 0.049 \\
\hline Area u / ROC curve & 0.670 & 0.751 & 0.669 & 0.659 & 0.769 & 0.761 & 0.671 & 0.698 \\
\hline Correctly Classified & 0.593 & 0.686 & 0.616 & 0.625 & 0.754 & 0.754 & 0.592 & 0.643 \\
\hline
\end{tabular}




\begin{tabular}{|c|c|c|c|c|c|c|}
\hline \multirow[t]{2}{*}{ Variable $^{a}$} & \multicolumn{3}{|c|}{ Model I } & \multicolumn{3}{|c|}{ Model II } \\
\hline & Cohesive & Noisy (0.1) & Noisy (0.2) & Cohesive & Noisy (0.1) & Noisy (0.2) \\
\hline Length $^{b}$ & & $\begin{array}{c}-180.8^{* *} \\
(85.3)\end{array}$ & $\begin{array}{c}-346.0^{* * *} \\
(126.4)\end{array}$ & & $\begin{array}{c}-212.5^{* *} \\
(89.1)\end{array}$ & $\begin{array}{c}-421.2^{* * *} \\
(133.9)\end{array}$ \\
\hline Binding & $\begin{array}{c}223.3^{* * *} \\
(83.1)\end{array}$ & $\begin{array}{c}168.6 \text { ** } \\
(63.7)\end{array}$ & $\begin{array}{c}145.3^{* * *} \\
(51.3)\end{array}$ & $\begin{array}{c}219.6^{* * *} \\
(82.2)\end{array}$ & $\begin{array}{c}159.6 \text { ** } \\
(65.5)\end{array}$ & $\begin{array}{c}130.5^{* *} \\
(54.3)\end{array}$ \\
\hline Pro-Labor court & $\begin{array}{c}-106.6^{* *} \\
(41.7)\end{array}$ & $\begin{array}{c}-169.0^{* * *} \\
(58.6)\end{array}$ & $\begin{array}{c}-144.6^{* * *} \\
(48.0)\end{array}$ & $\begin{array}{c}-100.7^{* *} \\
(43.5)\end{array}$ & $\begin{array}{c}-169.8^{* * *} \\
(57.7)\end{array}$ & $\begin{array}{c}-139.1^{* * *} \\
(47.0)\end{array}$ \\
\hline Post-Peron & $\begin{array}{c}328.2 \text { *** } \\
(39.2)\end{array}$ & $\begin{array}{c}323.1^{* * *} \\
(37.0)\end{array}$ & $\begin{array}{c}289.1^{* * *} \\
(29.7)\end{array}$ & $\begin{array}{c}328.7^{* * *} \\
(39.3)\end{array}$ & $\begin{array}{c}329.5^{\text {***}} \\
(35.5)\end{array}$ & $\begin{array}{c}293.5^{* * *} \\
(29.4)\end{array}$ \\
\hline Dictator & $\begin{array}{c}-256.8^{* * *} \\
(53.4)\end{array}$ & $\begin{array}{c}-337.7^{* * *} \\
(84.2)\end{array}$ & $\begin{array}{c}-322.1^{* * *} \\
(74.3)\end{array}$ & $\begin{array}{c}-258.8^{* * *} \\
(53.4)\end{array}$ & $\begin{array}{c}-365.5^{* * *} \\
(83.9)\end{array}$ & $\begin{array}{c}-357.2^{* * *} \\
74.2411\end{array}$ \\
\hline End Term & & & & $\begin{array}{c}15.7 \\
(23.0)\end{array}$ & $\begin{array}{c}37.2^{*} \\
(21.0)\end{array}$ & $\begin{array}{r}46.0 \text { ** } \\
(21.1)\end{array}$ \\
\hline _cons & $\begin{array}{c}132.5^{* * *} \\
(33.5) \\
\end{array}$ & $\begin{array}{c}216.7^{* * *} \\
(59.1)\end{array}$ & $\begin{array}{c}233.2^{* * *} \\
(57.8) \\
\end{array}$ & $\begin{array}{c}121.9^{* * *} \\
(39.4)\end{array}$ & $\begin{array}{c}209.2 \text { *** } \\
(58.1)\end{array}$ & $\begin{array}{c}226.9 \text { *** } \\
(55.7)\end{array}$ \\
\hline $\mathrm{N}$ & 62 & 62 & 62 & 62 & 62 & 62 \\
\hline Prob > F & 0.000 & 0.000 & 0.000 & 0.000 & 0.000 & 0.000 \\
\hline R-squared & 0.66 & 0.67 & 0.68 & 0.66 & 0.69 & 0.70 \\
\hline $\begin{array}{l}\text { Note: For each coe } \\
\text { parenthesis, below) } \\
a \text { All specifications } \\
b \text { Length is highly c } \\
\text { representation of le }\end{array}$ & $\begin{array}{l}\text { ficient, the } \mathrm{t} \\
{ }^{*} p<0.1 ; \\
\text { eclude three } \\
\text { Illinear with } \\
\text { islative part }\end{array}$ & $\begin{array}{l}\text { able shows th } \\
{ }^{* *} p<0.05 ;{ }^{* *} \\
\text { lagged obse } \\
\text { ro-Labor Co } \\
\text { es, and was }\end{array}$ & $\begin{array}{l}\text { e estimated } \\
p<0.01 \\
\text { rvations of th } \\
\text { urt, post-Perc } \\
\text { dropped from }\end{array}$ & $\begin{array}{l}\text { and robus } \\
\text { d dictator ir } \\
\text { analysis. }\end{array}$ & $\begin{array}{l}\text { standard err } \\
\text { the cohesive }\end{array}$ & rs (in \\
\hline
\end{tabular}


FIGURE 1. Court's best response with $\theta$ public information

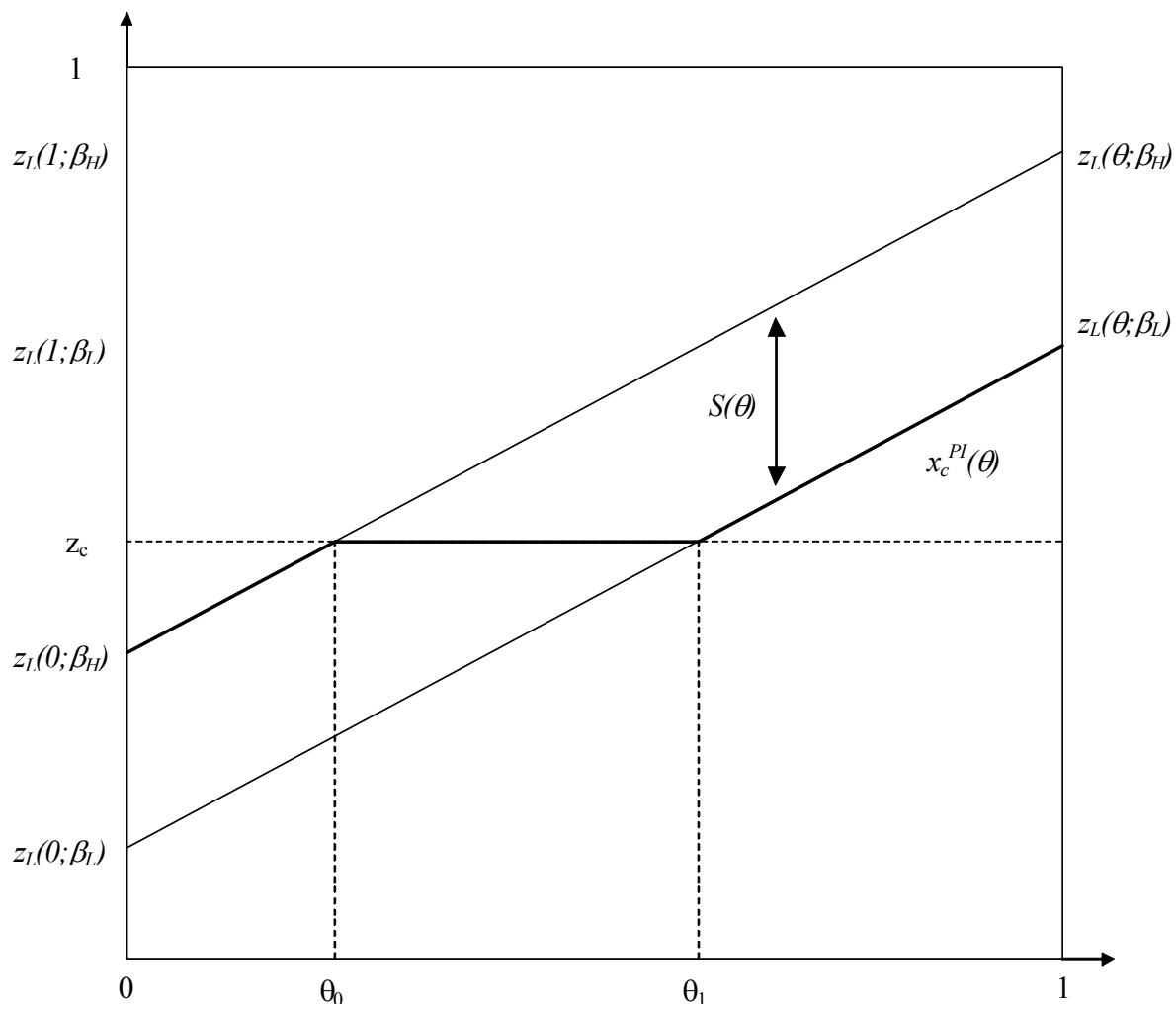

In the case depicted in Figure $1, z\left(0 ; \beta_{H}\right)<z_{c}<z\left(1 ; \beta_{L}\right)$. The court is perceived as "pro-labor" for $\theta<\theta_{0}$. Here the constraint is binding and $x_{c}^{P I}(\theta)=z_{L}\left(\theta ; \beta_{H}\right)$. Similarly, the court is perceived as "anti-labor" for $\theta>\theta_{1}$, and $x_{c}^{P I}(\theta)=z_{L}\left(\theta ; \beta_{L}\right)$. For $\theta \in\left[\theta_{0}, \theta_{I}\right]$, the court is unconstrained and $x_{c}^{P I}(\theta)=z_{c}$. 
FIGURE 2. Number of strikes in Argentina, 1935-1998

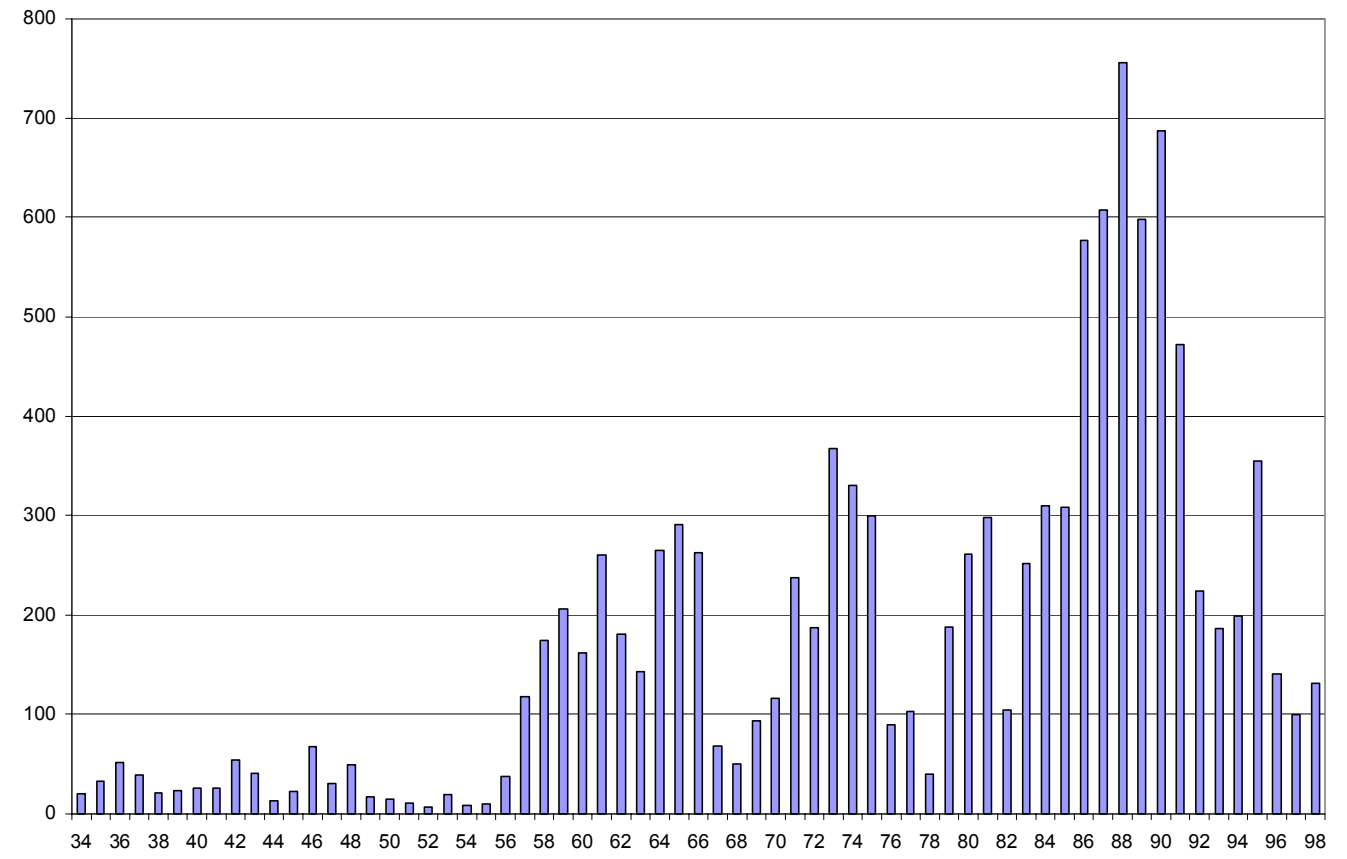


${ }^{1}$ For studies finding a relation, see Stratman 1992, 1995 and 1996. See also Snyder 1992.

${ }^{2}$ This is, for example, the case of El Salvador, where justices must be reappointed by the legislature. The budget could also serve as an instrument of influence. See Toma 1991.

${ }^{3}$ All results would go through employing Euclidean preferences with the usual properties. We present the analysis with specific functional forms to illustrate the nature of the results in closed form solutions.

${ }^{4}$ For completeness, there is a fourth stage in which the legislature reviews the court's decision, but given that courts would only make policy choices that are stable, we can without any loss, discard this last stage.

${ }^{5}$ See the appendix for a formal statement. Intuitively, this criterion requires that on observing a deviation (an action not taken with positive probability by any type of agent in the candidate equilibrium), the uninformed agents (court and union) will infer that the deviating party belongs to the class of agents who had the greatest incentive to make the observed deviation (Bernheim 1994).

${ }^{6}$ Note that this framework allows us to accommodate different procedures for legislative approval. For example, consider the case in which a policy has to be approved by two collective bodies (House and Senate, a committee and the floor, etc) by simple majority. In this case, $\beta_{L}$ and $\beta_{H}$ would be given by the median voters in each chamber, $S(\theta)$ would not in general be a singleton, and the court would face a nontrivial strategic problem. To simplify the presentation, however, we continue with the benchmark interpretation of a 
unicameral legislature with a supermajority rule unless it is otherwise noted, and drop the $m$ subscript when there can be no confusion.

${ }^{7}$ This should come as no surprise, however, since for this purpose, increasing $x_{c}$ with $\beta_{L}$ and $\beta_{H}$ given is qualitatively similar as simultaneously reducing both $\beta_{L}$ and $\beta_{H}$ taking $x_{c}$ as given, and we know from proposition 3 that $\beta_{L}$ and $\beta_{H}$ have opposite effects on the expected level of strikes.

${ }^{8}$ This will generally be the case even in systems as the Argentinean, where legislators' reelection rates are low, since the electoral connection constitutes an asset for other elective posts such as governors, majors and provincial legislatures. Moreover, this will generally also be the case even if, as in Argentina, party bosses control the nomination to party lists, since party bosses need to maintain the support of party members to retain the command of the party (see Iaryczower 2005).

${ }^{9}$ Peronism was banned from participating in the 1958 elections, and President Frondizi was elected with the explicit support of Peron (see, for example, McGuire 1997).

${ }^{10}$ This family of distributions is stochastically increasing in $\alpha$ and reduces to the uniform distribution when $\alpha=\beta=1$. Thus, the "noise" in the identification of the legislative parties with the President increases with $\alpha$.

${ }^{11}$ To clarify the second term in this expression, note that due to the symmetry of treatment, the proportion of legislators of the pro-labor party to the left of (more antilabor than) a given point $x$ in $[0,1]$ is equal to the proportion of legislators of the antilabor party to the right of (more pro-labor than) the point $1-x, 1-\mathrm{B}_{\alpha}(1-x)$. 
${ }^{12}$ Since these data were not available from a single source for our entire period (19351998), we selected what we considered to be the best possible source in our sample and generated the remaining data using the percent variation in the next best available series. The most comprehensive and reliable source is O'Donnel 2000, covering the period 1955-1972. For 1935-1955 we used data from Rotondaro 1971, which independently covers the period 1935-1968. For the period 1972-1998 we used Torre 1983, Fernandez 1988, and Nueva Mayoria 2001.

${ }^{13}$ By norms, we mean laws, presidential decrees, administrative decisions and resolutions. Cases in which the constitutionality of a lower court decision was questioned (arbitrariedad), and cases in which the constitutionality of the interpretation of a norm by a lower court was questioned, but not the norm in itself, were excluded. Moreover, we also excluded those cases in which the supreme court decided not to opine over the constitutionality of the challenged norm alleging formal or technical reasons. Finally, to avoid duplications in substance arising from the fact that the Argentine court does not have the ability to determine a law as unconstitutional per se, but rather has to deal with the unconstitutionality of its application to a particular case (person), we limit the pool of cases to those published in extenso in La Ley, the main judicial publication in Argentina. ${ }^{14} \mathrm{We}$ do this for the cohesive and noisy representations of the legislature. Note that the median voter in the Senate at the time of appointment, $T$, is computed from the distributions $G_{T}^{U}(x)$ and $G_{T}^{U}(x ; \alpha)$ respectively, and that therefore the measure of pro-labor court changes with each specification. 
${ }^{15}$ We do however also include a model specified for two thirds supermajority required in both chambers. Denoting the critical legislator for a pro-labor (anti-labor) coalition in chamber $j=U, L$ by $\beta_{L}^{j}\left(\beta_{H}^{j}\right)$, the critical legislator for pro-labor and anti-labor coalitions in this case are given by $\min \left\{\beta_{L}^{U}, \beta_{L}^{L}\right\}$ and $\max \left\{\beta_{H}^{U}, \beta_{H}^{L}\right\}$, respectively.

${ }^{16}$ Recall that we also treat military governments as completely unified, anti-labor governments, controlling both houses.

${ }^{17}$ The results presented in Tables one to three were obtained using STATA version 7.0.

${ }^{18}$ Recall that the relative positions of the court and of the critical legislators in the legislature vary with each specification. Thus, while there are no instances in which the political constraint is binding for a pro-labor court for "cohesive" parties, this event does indeed occur under a noisy representation of the legislature.

${ }^{19}$ The effect of dictatorships on pro-labor rulings should be considered in addition to the effect brought by a unified government (as we assume dictatorships imply unified governments). The results, however, may also reflect the nature of cases that come up for decision to the court in dictatorship periods (more intensively anti-labor) and in postPeron periods (more intensively pro-labor).

${ }^{20}$ The evidence, however, is not conclusive. On the one hand, while there are no instances of a pro-labor court being constrained by the legislature in the cohesive representation of the legislature, the coefficient of anti-labor constraint is not statistically significant in the noisy representations of the legislature (this is accentuated with $\alpha=0.2$, with a p-value of 0.729 ). On the other hand, however, rulings are always pro-labor when 
the constraint for an anti-labor court is binding. In this case, these observations carry no statistical information with respect to the likelihood function and have to be removed from the estimation. This is not to say that this variable is not relevant for the outcomes, but instead that its contribution can be replaced by the rule: "if a supermajority constraint is binding for an anti-labor court, the court will rule in favor of labor."

${ }^{21}$ We thank an anonymous referee for suggesting this exercise.

${ }^{22}$ We note, however, that length was highly collinear with pro-labor court, post-Peron and dictator in the cohesive representation of legislative parties, and was dropped from the analysis.

${ }^{23}$ We also find that the level of strikes decreases the more pro-labor the court is. As noted in the previous section, however, the empirical implication regarding the position of the court is ambiguous in general. Thus, although intuitive, this finding does not provide evidence in favor or against the model. 